\title{
Locus of hope and subjective well-being
}

Garcia, John Addy S.

Counseling and Educational Psychology Department, De La Salle University, Manila, Philippines (john.addy.garcia@dlsu.edu.ph)

\section{Sison, Karen Gayle}

Counseling and Educational Psychology Department, De La Salle University, Manila, Philippines (ksison24@yahoo.com)

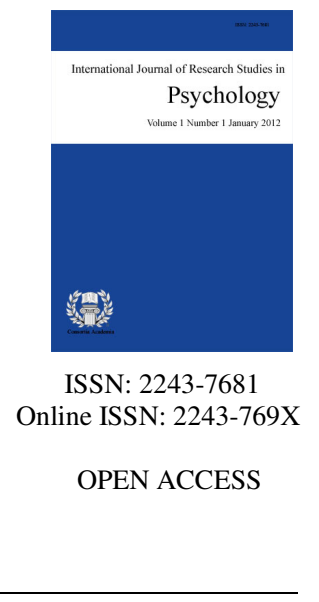

Received: 10 November 2012
Available Online: 30 December 2012

Accepted: 22 December 2012

\section{Abstract}

Hope theory (Snyder, 2002) posits that highly "hopeful" individuals are more successful in attaining their goals primarily due to the cognitive interplay between pathway and agency thinking or the ability to not only produce the necessary routes to a goal but also the motivation to actively pursue the routes created. Bernardo (2010) attempted to extend the theory through the incorporation of external factors that may contribute to an individual's level of hope thereby altering the highly internalized characteristic of hope. Although previous literatures have established the positive role of hope across different settings, there are relatively few studies on locus of hope as a whole. The current paper proposes to contribute to the expanding knowledge on locus of hope through setting possible research directions on the predictive capabilities of locus of hope as a whole on subjective well-being.

Keywords: Filipino; positive psychology; social goals; student life satisfaction 


\section{Locus of hope and subjective well-being}

\section{Introduction}

Going beyond the study of abnormal behavior and coupled by the interests of people in discerning the ways in which they can attain overall well-being (Linley, Joseph, Harrington \& Wood, 2006), the growth of positive psychology incited numerous research on ways in which humans can function optimally. As such, empirical studies on ways in which to attain life satisfaction and frequent positive emotions have significantly increased over time as well. As the field of positive psychology continuously expands, there is also a greater need to explore newer constructs to augment the existing structure and to further expand knowledge on how humans can attain a sense of well-being and optimal functioning.

\section{Hope}

A relatively growing area of study in the field of positive psychology and well-being involves Snyder's (2002) hope theory. Hope theory posits that individuals are constantly engaged in goal-oriented and goal-pursuant behaviors. There are two cognitions involved in the hope-laden thought process, specifically the pathways and the agency thinking, that would aid an individual in his/her goal attainment process (Bernardo, 2010, Snyder et al., 1991; Snyder, 2000; Snyder, 2002). Pathway thinking refers to a person's perceived capability to constantly generate the necessary routes that aids in goal attainment while agency thinking, on the other hand, refers to a person's perceived capability to actively and constantly engage in the routes that have been generated. As such, individuals who are "hopeful" are conceived to be more successful in attaining their goals as the constant cognitive interplay of both pathway agency thinking as it enables an individual to not only actively and constantly pursue the generated routes to their goals but to also overcome possible barriers along the way that may hinder goal attainment (Snyder et al., 1991; Snyder, 2000). Hope, in itself, is not an emotion (Snyder, Shorey, Cheavens, Pulvers, Adams, \& Wiklund, 2002) but it enables an individual to be at a relatively positive emotional state during the process of goal attainment (Snyder et al., 1991).

Locus of hope, on the other hand, is an extension of the hope theory (Bernardo, 2010). It premised that inclination to practice hope in itself is highly internalized, meaning that individuals themselves are solely responsible in being able to generate pathway and agency thinking. Though, it points out the possibility of incorporating the idea of external agents that could contribute to and influence an individual's goal attainment cognitions specifically the family, the peers and spiritual/supernatural beings and/or forces. It suggests that the generation of both pathways and agency thinking may be influenced by external factors specifically those that were previously mentioned, thereby extending the internalized characteristics of hope. In turn, an individual does not rely on his/her own capabilities to produce the necessary cognitions but acknowledge the importance of external agents as well (Bernardo, 2010). The reference of external agents in relation to hope cognitions stems from possible role of the family, peers and spiritual/supernatural beings or forces have been linked to its influence on an individual's goal-related pursuits (Church, 1987; Markus \& Kitayama, 2003; White, 2008) specifically in the generation of routes or the "ways" (pathways) as well the motivation or the "will" (agency) towards goal attainment (Bernardo, 2010).

The growing body of research on hope highlights the significance of the theory as well as its promising nature. For example, hope in itself has been shown to have a positive role in different domains from achievement to well-being and is evident in a growing number of literatures (Cheavens, 2000; Curry, Snyder, Cook, Ruby, \& Rehm, 1997; Hartley, Vance, Elliot, Cuckler, \& Berry, 2008; Peterson, Gerhardt, \& Rode, 2005; Rand, 2009; Snyder, Shorey, Cheavens, Pulvers, Adams, \& Wiklund, 2002; Sympson, 2000). Furthermore, hope has shown to be a "better" predictor of well-being compared to similar constructs (optimism and self-efficacy) due to the unique characteristics of hope against its counterparts (Magaletta \& Oliver, 1999). A growing number of research 
also centers on hope as positive influence on psychological well-being as well (Cheavens, 2000; Davidson, Wingate, Rasmussen, \& Slish, 2009; Hagen, Myers, \& Mackintosh, 2005; Sympson, 2000; You, Furlong, Felix, Sharkey, Tanigawa, \& Green, 2008).

\section{Subjective Well-Being}

Subjective well-being is not a fairly new construct. Subjective well-being as a construct involves both the cognitive and the affective evaluations of an individual with regards to his or her life wherein the experience of positive and negative feelings account for the affective domain and one's overall evaluation of life satisfaction accounts for the cognitive aspect (Diener, 1984; Diener, Emmons, Larsen, \& Griffin, 1985; Diener, Luca,s \& Oishi, 2002). Individuals associated with a high level of subjective well-being are characterized to be (1) contented with his of her life; and (2) experiences frequent positive emotions such as satisfaction and fulfillment rather than negative emotions such as depression and anger which in turn allow individuals to have positive experiences (Diener, Lucas, \& Oishi, 2002; Diener, Sandvik, \& Pavot, 1991).

Previous studies focused on how subjective well-being may improve aspects in one's life such as functioning and success (Diener \& Ryan, 2009) as well health, work, social relations and marriage (Lyubomirsky, King, \& Diener, 2005). Furthermore, recent researchers are now beginning to examine factors that may enhance well-being, particularly on the role of personality and trait and demographic variables which influence the overall subjective well-being of an individual (Diener \& Ryan, 2009; Sungh \& Udainiya, 2009).

\section{Hope on Subjective Well-Being}

Park, Peterson, and Seligman (2004) highlights that hopeful individuals tend to have a positive view about the future. In turn, these beliefs allows them to have a positive outlook about one's self that would aid in the increase their motivation (agency) and lead to culminate activities and means (pathways) that are directed towards actively pursuing personal goals (Hartley, Vance, Elliott, Cuckler, \& Berry, 2008). Hence, hopeful individuals can more likely succeed in their endeavors which allow them to gain a sense of fulfillment or satisfaction thereby increasing their subjective well-being.

It has also been pointed out that a positive outlook strongly affects how individuals cope with negative events and are able to approach problems with an eye for success, allowing them to have a bigger chance in attaining their goals (Snyder, Shore, Cheavens, Pulvers, Adams, \& Wiklund, 2002). Hope creates a relatively positive emotional state while goal attainment is being undertaken because the individual is focused towards his or her goal (Snyder, et al., 1991). With this, individuals who are high in hope feel more competent of their own skills which in turn allow them to be able to generate more ways (pathways) and sustain their motivation (agency) towards goal attainment to achieve goals in various aspects of their life thus increasing their chances of fulfilling their goals and gain a sense of satisfaction (Lyubomirsky, King, \& Diener, 2005) rather than harboring pessimistic thoughts about failure and challenges as threats that may contribute to negative feelings and emotions.

Beyond one's sole expectation and capability in attaining one's goal, studies have also shown how members of the family (Browne \& Shlosberg, 2006; Cicirelli, 1989), peers and friends (Cooper, Okamura, \& Gurka, 1992; Lyubomirsky, King, \& Diener, 2005; Markus \& Kitayama, 2003), God and other spiritual entities (Lim \& Putnam, 2010) play an important role in an individual's life (Bernardo, 2010), specifically, with regard to his or her subjective well-being.

Supportive relationships and social bonds have been revealed to be a factor in high subjective well-being (Diener \& Ryan, 2009). Individuals who have family members to support and help them with their goals tend to have higher levels of subjective well-being as family ties is emphasized in individuals, particularly in the Filipino culture (Church, 1987) wherein the importance of family members to each individual is shown by the high regard given to the members of the family in everything an individual engages in including how a particular 
goal is made and the means of executing ways to achieve them. There is no doubt that family plays an important role in the emotional and cognitive development of every individual (Sungh \& Udainiya, 2009; Church, 1987). It has been suggested that bonds between parents and children appear to be important to a child's well-being as parents are able to lower their child's anxiety their warmth and attention (Browne \& Shlosberg, 2006). In the study of Iyendar and Lepper (1999, as cited in Markus \& Kitayama, 2003), it has been suggested that parents, particularly the mother, serve as a source of support and motivating factor for individuals to perform the task they have to fulfill. Children who are guided by their mother in their decision-making process will more likely feel happy knowing that their mother, who has a strong influence in their lives, approves of their endeavor and are supported by them (Iyendar \& Lepper, 1999, as cited in Markus \& Kitayama, 2003). Furthermore, sibling relationships may also influence an individual's subjective well-being in such a way that sibling attachment or closeness makes a difference in their positive and negative affect (Cicirelli, 1989). When siblings are close, they tend to have a sense of security (Browne \& Shlosberg, 2006) that elicits positive affect. And when this happens, an individual will have lesser life stressors, enabling him or her to have more positive emotions which in turn would contribute to their subjective well-being.

Aside from that of the family, social bond among peers or friends can also be considered to have an effect on subjective well-being of an individual as well given that friendship have been found to increase a person's subjective well-being (Lyubomirsky, King, \& Diener, 2005). It has been pointed out that social relationship aid in the decrease of loneliness, depression, and jealousy and allows a person to be satisfied with their social activities and motivated to engage in them (Cooper, Okamura, \& Gurka, 1992) especially if they perceive that it is expected and demanded of them by significant others around them (Markus \& Kitayama, 2003).

From these empirical thrusts, conceptualizing hope as an individually-generated construct may be an assertion that is not necessarily valid, especially in collectivistic societies (e.g. Philippines, Japan, and Malaysia) where social and contextual variables are more prominent than individual variables. Given that previous literature strongly suggested on the positive impact of social variables in the achievement of positive emotions (e.g. happiness), construing a hopeful life orientation should also look at the influence of social units and interpersonally-relevant structures. Pathways and agency of hope may operate as cognitive expressions of individuals' motives for social connectedness and growth.

\section{Research directions}

Extant literatures that aim to explore hope in relation to subjective well-being allow room for future directions on the area of hope. Although relationships at the surface level can be seen between the proposed external aspects of hope and subjective well-being, the area of knowledge on locus of hope is quite limited. As opposed to the past conceptual standpoint that viewed hope as a highly individualistic construct, the recent framework of Bernardo (2010) emphasized the contextual elements that foster hopeful life orientations. That said, understanding hope as a phenomenon should highlight its social-contextual more than dispositional substrates, especially in societies where interpersonally-construed motives are highly valued.

Despite the empirical assertion that socially-relevant constructs are more salient predictors of well-being, it is promising to examine how externally-directed locus of hope may contribute to the attainment of joyous affective states. As examination of past researches implies a possible link between hope and subjective well-being, there is an urgent necessity to factor in on the mechanisms that underlie this association. Future researches are suggested to test the validity of currently existing models on hope. These possible paths for evidence-based formulations may further enhance theoretical structure and growth of hope as it relates to subjective well-being.

\section{References:}

Bernardo, A. B. I. (2010). Extending hope theory: Internal and external locus of trait hope. Personality and 
Individual Differences, 49, 944-949. http://dx.doi.org/10.1016/j.paid.2010.07.036

Browne, C. J., \& Shlosberg, E. (2006). Attachment theory, ageing and dementia: A review of the literature. Aging \& Mental Health, 10 (2), 134-142. http://dx.doi.org/10.1080/13607860500312118

Burton, K. D., Lydon, J. E., D’Alessandro, D. U., \& Koestner, R. (2006). The differential effects of intrinsic and identified motivation on well-being and performance: Prospective, experimental, and implicit approaches to Self-Determination Theory. Journal of Personality and Social Psychology, 91, 750-762. http://dx.doi.org/10.1037/0022-3514.91.4.750

Cheavens, J., Gum, A., \& Snyder, C. R. (2000). The trait hope scale. In J. Maltby, C. A. Lewis, \& A. Hill (Eds.), Handbook of Psychological Tests, Vol. I (pp. 248-258). Lampeter, Wales, UK: Edwin Mellen Press.

Church, A. T. (1987). Personality research in a non-western culture: The Philippines. Psychological Bulletin, 102, 272-292. http://dx.doi.org/10.1037/0033-2909.102.2.272

Cooper, H., Okamura, L., \& Gurka, V. (1992). Social activity and subjective well-being. Personality and individual differences, 13, 573-583. http://dx.doi.org/10.1016/0191-8869(92)90198-X

Curry, L. A., Snyder, C. R., Cook, D. L., Ruby, B. C., \& Rehm, M. (1997). Role of hope in academic and sport achievement. Journal of Personality and Social Psychology, 73(6), 1257-1267. http://dx.doi.org/10.1037/0022-3514.73.6.1257

Davidson, C., Wingate, L. R., Rasmussen, K., \& Slish, L. (2009). Hope as a Predictor of Interpersonal Suicide Risk. Suicide and Life-Threatening Behavior, 39(5), 499-507. http://dx.doi.org/10.1521/suli.2009.39.5.499

Diener, E. (1984). Subjective well-being. Psychological Bulletin, 95(3), 542-575. http://dx.doi.org/10.1037/0033-2909.95.3.542

Diener, E., \& Ryan, K. (2009). Subjective well-being: a general overview. South African Journal of Psychology, 39 (4), 391-406.

Diener, E., Emmons, R. A., Larsen, R. J., \& Griffin, S. (1985). The Satisfaction with Life Scale. Journal of Personality Assessment, 49, 71-75. http://dx.doi.org/10.1207/s15327752jpa4901_13

Diener, E., Oishi, S., \& Lucas,R. E. (2002). Subjective well-being: The science of happiness and life satisfaction. In C. R. Snyder \& S. J. Lopez (Eds.), Handbook of Positive Psychology. Oxford and New York: Oxford University Press.

Diener, E., Sandvik, E., \& Pavot, W. (1991). Happiness is the frequency, not the intensity, of positive versus negative affect. In F. Strack, M. Argyle, \& N. Schwarz (Eds.), Subjective well-being: An interdisciplinary perspective (pp. 119-139). New York: Pergamon.

Hagen, K. A., Myers, B. J., \& Mackintosh, V. H. (2005). Hope, social support, and behavioral problems in at risk children. American Journal of Orthopsychiatry, 75(2), 211-219. http://dx.doi.org/10.1037/0002-9432.75.2.211

Hartley, S. M., Vance, D. E., Elliott, T. R., Cuckler, J. M., \& Berry, J. W. (2008). Hope, self-efficacy, and functional recovery after knee and hip. Rehabilitation Psychology, 53(4), 521-529. http://dx.doi.org/10.1037/a0013121

Lim, C., \& Putnam, R. (2010). Religion, social networks, and subjective well-being. American Sociological Review, 75(6), 914-933. http://dx.doi.org/10.1177/0003122410386686

Lyubomirsky, S., King, L., \& Diener, E. (2005). The benefits of frequent positive affect: Does happiness lead to success? Psychological Bulletin, 131, 803-855. http://dx.doi.org/10.1037/0033-2909.131.6.803

Magaletta, P. R., \& Oliver, J. M. 1999. The hope construct, will and ways: Their relations with self-efficacy, optimism, and well being. Journal of Clinical Psychology, 55(5), 539-551. http://dx.doi.org/10.1002/(SICI) 1097-4679(199905)55:5<539::AID-JCLP2>3.0.CO;2-G

Markus, H. R., \& Kitayama, S. (2003). Models of agency: Sociocultural diversity in the construction of action. In V. Murphy-Berman \& J. J. Berman (Eds.), Crosscultural differences in perspectives on the self (pp. 1-57). Lincoln, NE: University of Nebraska Press.

Park, N., Peterson, C., \& Seligman, M. (2004). Strengths of character and well-being. Journal of Social and Clinical Psychology, 23, 603-619. http://dx.doi.org/10.1521/jscp.23.5.603.50748

Peterson, S. J., Gerhardt, M. W., \& Rode, J. C. (2005). Hope, learning goals, and task performance. Personality 
and Individual Differences, 87, 1099-1109.

Rand, K. L. (2009). Hope and optimism: Latent structures and influences on grade expectancy and academic performance. Journal of Personality, 77(1), 231-260. http://dx.doi.org/10.1111/j.1467-6494.2008.00544.x

Snyder, C. R. (2000). Hypothesis: There is hope. In C. R. Snyder (Ed.), Handbook of hope: Theory, research, and applications (pp. 3-21). Orlando, FL: Academic. http://dx.doi.org/10.1016/B978-012654050-5/50003-8

Snyder, C. R. (2002). Hope theory: Rainbows of the mind. Psychological Inquiry, 13(4), 249-275. http://dx.doi.org/10.1207/S15327965PLI1304_01

Snyder, C., Harris, C., Anderson, J. R., Holleran, S. A., Irving, L. M., Sigmon, S. T., et al. (1991). The Will and the Ways: Development and Validation. Journal of Personality and Social Psychology, 60(4), 570-585. http://dx.doi.org/10.1037/0022-3514.60.4.570

Snyder, C., Shorey, H. S., Cheavens, J., Pulvers, M. K., Adams III, V. H., \& Wiklund, C. (2002). Hope and Academic Success in College. Journal of Educational Psychology, 94(4), 820-826. http://dx.doi.org/10.1037/0022-0663.94.4.820

Sungh, B., \& Udainiya, R. (2009). Self-efficacy and well-being of adolescents. Journal of the Indian Academy of Applied Psychology. 35(2), 227-232.

Sympson, S. C. (2000). Rediscovering hope: Understanding and working with survivors of trauma. In C. R. Snyder (Ed.), Handbook of hope: Theory, measures and applications (pp. 285-300). San Diego: Academic Press.

White, K. R. (2009). Connecting religion and teacher identity: The unexplored relationship between teachers and religion in public schools. Teacher and Teaching Education, 25, 857-866. http://dx.doi.org/10.1016/j.tate.2009.01.004

You, S., Furlong, M. J., Felix, E. D., Sharkey, J. D., Tanigawa, D., \& Green, J. G. (2008). School connectedness as a mediator of the relation between bullying victimization and hope and life satisfaction. Psychology in the Schools, 45(5), 446-460. http://dx.doi.org/10.1002/pits.20308 